(C) This is a post-peer-review, pre-copyedited version of an article published in The Witness and the Text, ed. Debra Kelly and Gill Rye, special issue of Journal of Romance Studies 9.3 (Winter 2009), pp.48-59.

The ethics of aesthetics of trauma fiction: memory, guilt and responsibility in Louise L. Lambrichs's Journal d'Hannah

\title{
Gill Rye
}

It is a contention of much recent literary criticism that fictional texts play an important role in the witnessing of traumatic events. In trauma studies, trauma is characterized by unrepresentability, inexpressibility, and its inability to be assimilated into narrative: for Cathy Caruth (1996), for example, trauma is known only in the way it returns to haunt the individual, often many years after the original event. For Anne Whitehead (2004: 83), though, by the very nature of its creativity, innovation, literary devices and techniques, fiction is able to represent what 'cannot be represented by conventional historical, cultural and autobiographical narratives'. The ways in which it can do this include mimicking the 'symptomatology' of trauma, by means of 'recurring literary techniques and devices', such as fragmentation, ellipses, repetition, recurring motifs, tropes, etc. (85). For their part, Victoria Best and Kathryn Robson (2005: 7) suggest that the irresolvable tensions between the individual and the collective', to which the study of cultural memory draws attention, can be productive in works of imagination, in order to 'provide acute perspectives on the interrelation of experience and knowledge through networking acts of memory' (6). Max Silverman 
(2008: 426) argues the case for similar kinds of connections to be made in the study of literature: 'the metaphorical imagination (seeing one thing in terms of another) allows for the perception of similarities and differences, repetitions and transformations'. Silverman's point is that, rather than simply being a comparison of different histories in possibly hierarchical ways, such connections can be productive in opening up insights and understanding.

Nonetheless, the creation of what then becomes a literary aesthetics of trauma raises the inherent problematic of ethics - the risks of reduction, appropriation, and losing sight of the historical specificity of the traumatic event. Whitehead (2004: 84) defines as 'trauma fiction' texts that interact with trauma theory through the exploration of "new modes of referentiality, which work by means of figuration and indirection' and, ultimately, by the generation of an ethical reading practice, 'a mode of bearing witness' (8), and this is a particular challenge where Holocaust memorialization is concerned.

This article focuses on contemporary French author Louise L. Lambrichs's novel Journal d'Hannah (1993) [Hannah's Diary], a fascinating example of trauma fiction, about which little has yet been written. ${ }^{1}$ It is worth attention because, first of all, it portrays an unusual psychological response to traumatic experience; secondly, it explores the relationship between the private and the public, between the individual and History, in relation to traumatic events, particularly the Holocaust; and, thirdly, it addresses issues about the ethics of contemporary literary representation and the role of writing - and reading. The internal dynamic of the novel is based on a mirroring structure, and, in accordance with Whitehead's points above, I engage with the ethical implications of this dynamic. The particular mirroring that takes place in Lambrichs's text might suggest that the personal trauma of a wartime abortion in some sense 
stands for (or can even be compared to) the trauma of the Holocaust. Much debate in memory studies has engaged with precisely this problematic; in bringing different kinds of traumatic events together with the Holocaust, how far are they being compared, and does this then deny the singular horror of the Nazi genocide? ${ }^{2}$ My argument is, however, that, rather than setting up such an equation, Lambrichs's novel brings into play another series of mirror-images, and that, ultimately, it engages with issues of guilt and responsibility, specifically in relation to France's collaboration with Nazi persecution of the Jews and to its role in the Holocaust.

The novel takes the form of a diary, which runs intermittently from 1943 to 1962. ${ }^{3}$ The narrator-protagonist - or diary writer - is Hannah Périer, a Belgian Jewish woman (who, however, up until the war, had never identified as Jewish). She is married to a French gentile man and living in Paris (and later in the countryside near Versailles). In 1943, Hannah (who temporarily takes the name Anne in order to conceal her Jewish identity in Nazi-occupied Paris) becomes pregnant and, very reluctantly, has an abortion in a Swiss clinic at the instigation of Robert, her Resistance activist husband. Fearing they may need to flee Paris in order to protect Hannah, Robert cannot countenance another child (the couple already has a young daughter, Colette). Meanwhile, Hannah is without news of her parents and sister in Belgium, whom she later discovers to have been deported and to have perished in the Holocaust. This multiple trauma - the coerced abortion, the loss of her family, the Holocaust - predictably mark Hannah for life.

While still pregnant, Hannah dreams of her baby, and, after the rather late abortion of the baby girl, these dreams continue... for the next twenty years. Hannah's dreams are particularly unusual, not only for their duration, but also because they are more like waking dreams. They neither follow the normal oneiric logic of 
condensation and displacement, the blurring of time, place and identity, nor do they constitute repetitive flashbacks, the reliving of the past as if it were the present, which is a common effect of trauma. Rather, in Hannah's fantastic dream world, which she keeps completely secret for fear of being considered mad, Louise - as she names the daughter who was aborted - lives and grows up in real time, just as if she had not died. Significantly, Hannah's lost family also populate this haunted dream world.

Lambrichs's novel is one of several on the topic of abortion by contemporary women writers, to the extent that Christine Détrez and Anne Simon describe it as 'un nouveau topos littéraire' (Détrez and Simon 2006: 143) ['a new literary topos']. ${ }^{4}$ That the novel works on several levels is confirmed by the variation in its press reviews. Some reviewers of the novel, for example Michèle Bernstein (1993) and Wendy N. Greenberg (1995), read it as an anti-feminist or anti-abortion text. Others, like J.-M. de Montremy (1993) and Jacqueline Remy (1993), describe it as a psychological drama, while Caroline Eliacheff and Nathalie Heinich (2002: 356-8) refer to Lambrichs's novel as an example of a mother's difficulty in mourning the loss of a daughter. However, some reviewers, such as Viviane Forrester (1993), Pascale Frey (1994) and Monique Verdussen (1993), are more attentive to the historical setting of the novel and have interpreted it as a contribution to the memorialization of the Holocaust.

In Lambrichs's text, Hannah's dreams are, undoubtedly, her psyche's way of protecting itself in the face of traumatic loss. They are testimony to the 'ongoing experience of survival', to the 'endless impact on a life' that trauma signifies (Caruth 1996: 7). This dimension of the work has been explored by Victoria Best (2002), who, in the only substantial study of Lambrichs's novel to date, analyses it in terms of both the limits and the creativity of dreams in relation to trauma. While inspired by Best's 
insightful analysis of Hannah's dream life and the workings of the psyche in relation to traumatic loss within the novel, my own discussion of the ethics of the literary aesthetics of the text necessarily takes a somewhat different path. First, I analyse the structuring dynamics of the novel, then I turn to the historical context of its setting and writing, before going on to assess the ethical impetus of this strange and haunting example of trauma fiction.

\section{The literary text}

According to Lambrichs, the diary format imposed itself on the novel: 'c'était la seule manière de l'écrire puisqu'il s'agit de la vie intime d'Hannah' (Frey 1993) ['it was the only way to write it since it concerns Hannah's intimate life']. It also enables a quasimetafictional, reflective dimension, which I will come back to later. The text is dated chronologically, to evoke a diary that is kept intermittently over a number of years (see note 3 for the main structure). Within each of the five periods - 1943, 1947, 1948, 1954 and 1962 - uneven gaps occur in the diary entries, sometimes days, sometimes weeks and sometimes months. Some entries are very short, just a line or two, others are several pages long. As well as reflecting the fragmentation and ellipsis symptomatology of trauma, this kind of uneven format also reinforces the vraisemblance of the novel as a diary, which is in fact based on a real medical case study. ${ }^{5}$ The choice of historical setting and thus the decision to link the trauma of the abortion with that of the Holocaust are, however, Lambrichs's own.

Lambrichs's narrator/protagonist Hannah lives a double life as if in two, mirrored, dimensions - those of dream and reality, those of her internal, mental life and her external, social life - and this mirroring forms the structuring dynamic of the novel. The mirroring does not appear as a motif as such (there are no mirrors in the 
novel) but it is borne out in a number of different ways. Many of the characters have mirror images; most notably, Hannah's young daughter Colette is mirrored by her dream child Louise. Colette's doll, which she also (uncannily) names Louise, provides yet another version of this. Other instances include Hannah's friend Elizabeth, who reminds Hannah of her lost sister, and, at one point, Elizabeth becomes Hannah's own mirror image, since, when Hannah has a breakdown, her friend takes her place in her house, in Colette's and Robert's affections, and even in her bed. Robert, Hannah's husband, is reflected in Michel, Hannah's doctor, lover and then friend, and Robert's postface to the diary, with which the novel ends, serves as a reminder that mirror images involve difference as well as sameness when Robert reveals, or claims, that he does not recognize himself as the Robert of Hannah's diary. This is, of course, also a comment on identity, and, further, a mise-en-abyme of the fictional process.

Another example of mirroring in the novel is a recurring house motif. In the first instance, Hannah dreams of a big house in the country, in which she spends quality time with Louise and her parents. Second, Colette paints a canvas for her mother as a Christmas present, which portrays what appears to be exactly the same house, with two little girls playing outside (it is this painting which sparks Hannah's breakdown). Third, many years later, when the family moves out of Paris, the house in Colette's painting is identified as a real building nearby; the occupants (a Jewish couple with two little girls) had tragically been deported during the war. And, fourth, this same house is subsequently bought by Colette's parents-in-law, and another, more recent tragedy, linked to the first, is found to have occurred there: the son of the gardiens of the house kills his father, then himself, and his mother goes mad. The text suggests, though does not confirm, that this was because the son had belatedly 
discovered that it was his father who had informed on the Jewish family during the war.

While this kind of recurring (haunted or uncanny) house motif, together with the use of the mirror-image Doppelgänger, could be traced to potential literary influences on Lambrichs - the gothic novel, the fantastic, and also perhaps surrealist coincidences and oneiric logic - here, the mirroring dynamic has an even deeper root, in the author's own biography. Her father was an identical twin and, in 'À notre image?' ['In our image?'], her preface to the second edition of her novel about cloning, À ton image (1998) [In your Image], Lambrichs relates her interest in cloning to her experience of being part of 'une famille en miroir' (Lambrichs 2004: 15) ['a mirror family'] (her uncle, who lived in Belgium, also had two daughters like his brother). The influence of this 'mirror family' on her writing of the earlier Journal d'Hannah is suggested by Lambrichs's naming of Hannah's two daughters: Louise (after herself) and Colette (after one of her cousins). ${ }^{6}$

In the novel, the chain of mirrors involving different versions of the house connects Hannah's traumatic abortion with the Holocaust at the level of both literary aesthetics and signification, suggesting that the connections between individual and collective trauma are what are really important in this text. Indeed, both the abortion and the Holocaust are lived as deep and open wounds in this novel, and Hannah considers her baby to be 'une victime de cette guerre ignoble' (Lambrichs 2002: 39) ['a victim of this unspeakable war'] as much as her family is. Moreover, the doubling motif of the house with its two little girls, recurring at key points across the extent of the novel, from start to finish, serves to intensify the long-lasting sense of trauma and loss that the novel inscribes: the two girls first mirroring Hannah's two daughters (Colette who lives and Louise who was aborted) and then Hannah herself and her 
sister (the latter deported and dying in the Holocaust, the former escaping that fate). But is this the sum of what is behind Lambrichs's choice of setting for her fictionalized version of a real-life case study? In order to explore this question further, I now turn to consider the historical contexts of the setting and the writing of the novel.

\section{Historical context: issues of guilt and responsibility}

Hannah's traumatic response to both the abortion of her daughter and the loss of her parents and sister involves a great deal of guilt and explicitly raises questions of responsibility. Haunted by her dreams, Hannah is consumed by guilt, over the abortion, on the one hand, and over the loss of her family in the Holocaust, on the other. As far as the abortion is concerned, Hannah's guilt does not seem to revolve around the illegality of abortion in France at that time, although it is a factor, especially as it makes abortion a taboo, a guilty secret that must be kept. ${ }^{7}$ In choosing Switzerland as the venue for the termination, however, Lambrichs obviously does not mean to dwell on the illegal aspects (as opposed to Ernaux [2000] who recounts an illegal abortion within France). Nonetheless, it implicitly puts Hannah outside the law, and thus reinforces (mirrors) the already and more dangerous clandestine nature of her position as an undeclared Jewish woman in occupied Paris. Hannah feels so guilty over such a long period of time because she feels implicated in killing the child she wanted so much, especially given the historical context of the Holocaust, where so many Jews, including babies, were murdered. In her own eyes, she too is partly responsible for killing a Jewish baby.

Hannah's guilt increases when she finds she is sterile due to the abortion; thus she has lost not only one child but implicitly all the children she could have had and 
she is unable to give her daughter Colette any siblings. This occurs at a time when postwar pronatalist discourse was emphasizing women's mission to repopulate France; because of her late abortion, Hannah is unable to play her part in the 1950s baby boom and the reconstruction of the nation.

Though paralysed by guilt, at the outset Hannah does not accept responsibility, seeing herself only as a victim, blaming her doctor even more than her husband for forcing her to have an abortion:

Je ne peux pas me défaire de l'idée que sans lui [the doctor], sans sa complicité lâche et coupable, je porterais encore mon enfant. Une ou deux semaines de plus, et Robert aurait capitulé devant le danger qu'une telle opération me faisait courir. (Lambrichs 2002: 33)

[I can't get rid of the idea that if it hadn't been for him, for his cowardly, guilty agreement, I would still be carrying my child. Another week or two and Robert would have given in, because the operation would have been too dangerous to put me through. (Lambrichs 1998: 20)]

After the war, however, Hannah's perspective and sense of responsibility begins to change: 'la mort de Louise, ce meurtre que nous partagions mais dont il portait plus que moi la responsabilite' (65-6) ['the death of Louise, that murder we shared but which was more his responsibility than mine' (47)]; and 'cette enfant qu'il a tuée, que nous avons tuée' (97) ['this child that he killed, that we killed' (73)]. While still largely blaming Robert, here she begins to accept some responsibility on her own account. Finally, after the cessation of her dream life, Hannah's perspective has 
evolved still further: 'le prix payé pour le crime, ce crime qu'avec Robert j’ai partagé, mais dont je suis sans doute la seule responsable' (268) ['the price paid for the crime, the crime I shared with Robert, but for which I am probably the only one responsible' (218)]. Here, Hannah finally accepts more or less full responsibility. During the course of the novel, then, her sense of self moves across the full spectrum from victim, to collaborator, to perpetrator.

Hannah also suffers from guilt in relation to her deported and murdered family: the guilt of survival. This common reaction to traumatic loss is exacerbated by the fact that, in changing her name in order to save herself, Hannah effectively denied the Jewish identity neither she nor her family had ever really claimed, but for which they had died while she lived. She also relates her post-abortion sterility to survivor guilt, mourning the 'seul acte qui à mes yeux justifiait la mienne' (90) ['only act that justified my own life in my own eyes' (68)] in terms that reveal her view of reproduction as reparative. For Hannah, to give birth again would have been a redemptive act.

In a further case of mirroring, Hannah's trajectory is reflected in French history. The postwar heroic discourse of the French Resistance is juxtaposed with its long-unspoken underside - collaboration, complicity, informers, anti-Semitism - at the level of both the individual (represented by the gardien of the house near Versailles) and the state (by means of Hannah's reflections on France's postwar legacy):

La France, complice pendant quatre ans d'un pouvoir criminel, n'a-t-elle pas en fait perdu la guerre? [...] Les véritables gagnants de cette guerre sont l'Amérique et l'Angleterre. Elles seules ont évité la collaboration avec les 
nazis. Tous les autres pays ont été touchés, contaminés. La France la première, il ne faut jamais l'oublier. [...] L'antisémitisme en France est une maladie endémique, sujette à rechutes. [...] [A]ucune victoire, jamais, aucun traité, aucune signature ne la lavera d'un passé dont seule la mémoire entretenue peut prévenir l'aveugle retour. (216-18).

[By being an accomplice for four years of a criminal power, France can surely be said to have lost the war? (...) The countries that really won the war were Britain and the USA; they alone avoided collaboration with the Nazis. Every other country was affected, contaminated, France most of all, something that should never be forgotten. (...) Anti-semitism is endemic in France, always liable to break out again. (...) (N)o victory, no treaty, no signature at the bottom of a document can ever wash away a past that can only be prevented from repeating itself if we keep the memory of it alive. (172-3)]

Hannah's view of herself as first victim, then collaborator and, finally, perpetrator, mirrors the situation of postwar France, about which debate was rife at the time Lambrichs wrote and published the novel. Following several decades in which French collaboration with the Nazis was repressed or silenced, during the 1980s and 1990s France was gripped by 'une frénésie obsessionnelle de la commémoration' (Lasserre 2002: 327) ['an obsessional frenzy of commemoration']. A series of controversial war crime trials was held; the last, the Papon trial, of a French policeman for the deportation of Jews, did not take place until 1997-8, but it was preceded by fourteen years of legal wrangling. In the early 1990s, at the time Lambrichs was gestating and writing the novel, then, French culture was permeated 
by the discourse of guilt and responsibility (see Wolf 2004). President François Mitterand fell short of officially acknowledging France's responsibility for the parts French police and civil servants played in the deportation of the Jews during the war, despite a great deal of petitioning and lobbying. He did, however, commission a monument for the site of the rafle $d u$ Vel' d'hiv in 1942 - this event involved a massive round-up of Jews, including large numbers of children, at the winter velodrome in Paris, before their deportation to camps in France and thence to Auschwitz and death. President Jacques Chirac only finally acknowledged France's responsibility for the rafle $d u$ Vel' d'hiv and other atrocities in $1995 .^{8}$

\section{The ethical impetus of Journal d'Hannah}

So far, then, we have seen how the mirroring structure of Lambrichs's novel links Hannah's personal trauma of an abortion to the Holocaust by means of the parallel trauma of losing her family. Moreover, Hannah's own progression of guilt and responsibility mirrors that of postwar France. But how far does this mirroring aesthetic generate the kind of ethical reading practice that Whitehead (2004: 8) requires of trauma fiction? Given the extent of the novel's mirroring structure, Hannah's aborted daughter Louise could be seen as a literary symbol for other children lost in the Holocaust but, as we have seen, the mirroring dynamic also constitutes an exploration of guilt that renders this novel more complex, and this is where, I argue, its principal ethical impetus lies.

As mentioned above, Hannah's diary entries also include an important reflective element. On the one hand, she muses on her diary writing, on the role that writing plays in holding on to her self-identity, in externalizing her dream life, and, importantly, in working through her traumatic response and her own feelings of guilt 
and responsibility. On the other hand, she reflects on Jewish identity, and on questions around remembering and forgetting, on 'ces plaies qui jamais ne se referment' (79) ['these wounds that never heal' (58)] and 'la mission [...] de se souvenir. Pour les suivantes' (114) ['our mission (...) to remember. For the generations to come' (88)]. Here, her reflections look beyond her own problems to issues with which French society is grappling: wartime collaboration, ongoing anti-Semitism and racism, and the even more universal issues of humanity, war, peace and ethics.

Before concluding, it is necessary to address two further aspects of Lambrichs's novel. The first is the issue of resolution. Hannah is ultimately cured of her dreams of Louise after she pours out her story to a new doctor: 'Ce fut plutôt une espèce de vomissement entrecoupé de larmes, comme si tout mon corps participait à l'expulsion de ce rêve impossible' (261) ['I had to tear it out of myself as if I were vomiting, and I kept bursting into tears, as if my whole body was conspiring to expel this impossible dream' (211)]. From that time on, she sleeps well and no longer dreams of Louise. Is this simply Lambrichs's rather (too?) neat happy ending, and, if so, what would that imply in terms of the mirroring dynamic of the novel?

Undoubtedly, this resolution to Hannah's problems reflects Lambrichs's own interest in psychology and psychoanalysis - the year of the publication of Journal d'Hannah also saw her study of Freud (Lambrichs 1993). The resolution also, of course, dialogues with trauma theory; ultimately, Hannah is able to narrate the story of her trauma to a listener who bears witness to it. However, the novel's postface, narrated by Robert, now Hannah's widower, goes some way to complicating this somewhat abrupt - if manifestly positive - ending to Hannah's dream life, since it reveals that Hannah died of cancer aged 64 after fifteen years of struggling against the disease (interestingly, Lambrichs [1995] has also written about the psychoanalytical 
treatment of cancer sufferers). If, as I have intimated, the character of Hannah can be considered as a cipher for French postwar guilt, her cancer would also carry metaphorical implications, and Lambrichs is surely suggesting here that, even in acknowledging responsibility for wartime crimes, the French state has still not resolved its relationship to a murky past.

The second aspect of the novel still requiring discussion is the question of transmission. To what extent is trauma considered to be carried over from one generation to another? At first, Lambrichs's novel seems to suggest that Hannah's unspoken, traumatic response is being transmitted to her daughter Colette: Colette names her doll Louise, the name her mother has given to her dream daughter, and she also represents the house of Hannah's dreams in her painting. Psychoanalysts Nicolas Abraham and Maria Torok (2001) posit a kind of intergenerational transmission whereby the next generation is haunted by the phantom of a family secret. In Lambrichs's novel, the recurring house motif first suggests to the reader that such a transmission is taking place (between Hannah and her daughter Colette). However, this is ultimately undercut, when Hannah comments 'des maisons de ce genre, il en existe des centaines' (235) ['there must be hundreds of houses in France that look much like this one' (188-9)]. The house near Versailles, which resembles so much the house of her dreams and Colette's painting, is revealed to be only one of many of its kind, and the literary motif, which has hitherto suggested the intergenerational transmission of trauma, is represented as simply a coincidence. Similarly, when Colette miscarries her first child, Hannah's fears that her daughter will suffer a similar traumatic reaction to her own are allayed when Colette takes it philosophically. These developments may, however, be rather too neat - much like the 'happy ending' discussed above. Yet their very neatness serves precisely to disturb the reader from 
too straightforward a reading. So, rather than conforming to Abraham's and Torok's phantoms which are the 'subject of shame and prohibition' as it might at first seem, the form of haunting that takes place in this novel is, instead, more 'a productive opening of meaning' (Davis 2005: 378, 377), which leads us out of the text to interrogate issues of guilt and responsibility more widely. ${ }^{9}$

The reflective dimension of Hannah's diary entries situates her experiences and traumatic response - and, indeed, our reading of them - in a wide frame. Rather than simply linking individual and collective trauma, Lambrichs's Journal d'Hannah is also an innovative engagement with France's belated efforts to come to terms with, to work through, the dark aspects of its wartime past, a past which, as Johnnie Gratton (2005: 43) notes, 'until very recently [...] held only a small place, and a highly doctored one at that, in France's collective memory', and which, according to Warren Motte (2008: 43), remains 'for many French an open wound, a shameful and painful memory'. In this respect, memory theorist Dominick LaCapra (1998: 185, 186) argues for 'working through' as an 'ethical process', 'most effective when it is situated in social and political contexts', citing as 'a crucial question [...] how one may further the difficult process of moving from victimhood to survival, witnessing, and agency'.

Yet the novel leads us beyond the specific historical context of the events and aftermath of the Second World War. It is noteworthy that 1954 and 1962 are two of the years Lambrichs chooses for Hannah's postwar diary entries; the Algerian war, which divided France between those years, is not mentioned in the novel but, given Hannah's reflections on war, French responsibility and questions of humanity, it functions as another spectral presence. Furthermore, in interview, when asked why she chose to set her fictional version of the real medical case history in wartime France, Lambrichs responded thus: 
Je me suis toujours demandé pourquoi il y avait des gens qui savaient et d'autres qui ne savaient pas. Je trouve aussi que c'était une période qui ressemblait beaucoup à la nôtre. Il n'y a qu'à voir ce qui se passe en Yougoslavie aujourd'hui. Là aussi il y a ceux qui savent, et ceux qui ne savent pas. (Frey 1993)

[I have always wondered why some people knew and others didn't. I also think that period is very much like our own. You only have to look at what is going on in Yugoslavia today. There too, there are those who know and those who don't.]

Here, Lambrichs suggests a further historical connection, between the issues of postwar French memory (complicity, collaboration and perpetration) evoked in the novel and the situation in the former Yugoslavia at the time of her writing it. ${ }^{10}$ In doing so, she emphasizes the contemporary and ongoing nature of these issues, in France and beyond. Connections between different instances of human complicity with atrocity (or even simply passivity on the part of those who are aware it is happening) are clearly what are being made here rather than connections or comparisons between the atrocities themselves.

The publication of Hannah's diary announced in Robert's postface suggests, intradiegetically, the ethical reading practice proposed by Whitehead's trauma fiction - writing and reading as a form of bearing witness. The strength of Lambrichs's Journal d'Hannah in this respect is that the novel bears witness not only to an individual trauma but also to the trauma - and to the implication in atrocity - of a 
culture, of a state. Here, the ones who bear witness, the readers (particularly but not exclusively French readers), are invited to take an active part in the ethical process of working through. By means of its mirroring structure and Hannah's reflections on war and responsibility, the novel leads us all, as readers, to interrogate our own responsibility in relation to the wars and atrocities that are still proliferating in our time, and to what is being done to fellow human beings in their name.

\section{Notes}

1 Journal d'Hannah was nominated book of 1993 by Lire magazine, was short-listed for the Prix Renaudot and the Prix Femina, and has been translated into several languages. Louise L. Lambrichs (b.1952) has published a number of novels and essays, including texts on medical and historical topics.

2 See, for example, LaCapra (1998: ch. 2); Miller and Tougaw (2002: introduction); and, in the French context, Todorov (1998) and Wolf (2004). The linking of individual trauma with collective trauma and atrocity is also to be found elsewhere in French cultural production, for example, Alain Resnais's film Hiroshima mon amour (1959), and, more recently, Michael Haneke's Caché (2005). See also Best and Robson (2005).

3 The first part, January-June 1943, takes place in occupied Paris; the second part, March-December 1947, in post-liberation Paris; the third part - end January-mid February 1948 - continues from the previous part, with a gap of a month coinciding with (and signifying) the diarist's breakdown; the fourth section, July-November 1954, follows her family's move out of Paris to a village near Versailles; the fifth part, March-November 1962, relates to the termination of her diary writing; and this is followed by a three-page postface [epilogue] in the voice of her husband/widower. 
4 Other examples include Ernaux (1974, 2000), Gazier (1995), Nobécourt (1998), Darrieussecq (1996), Cusset (2001) and Huston (1996). See Sardin (2008) for an analysis of Ernaux (2000) and Huston (1996).

5 See Frey (1993): a doctor told Lambrichs about a patient who consulted him after twenty-five years of insomnia paradoxically combined with real-time dreams of a child she had aborted.

6 Perrier (2004) mentions that Lambrichs's cousin Colette worked for Éditions de la Différence, which published both her first novel and Journal d'Hannah. In interview, Lambrichs relates how, after mulling the topic over for several years, once she had decided to call the lost baby Louise, she was able to start writing the novel ... (Frey 1993).

7 Abortion only became legal in France in 1975, and in Vichy France it was even considered to be a crime against the state and abortionists were guillotined.

8 See Rosnay (2007) for a fictional treatment of the rafle $d u$ Vel' d'hiv and its memorialization.

9 Colin Davis makes this distinction between Abraham's and Torok's 'phantoms' and Derrida's 'spectres' in his article on hauntology as an endeavour to make literary study 'a place where we can interrogate our relation to the dead, examine the elusive identities of the living, and explore the boundaries between the thought and the unthought' (Davis 2005: 379).

10 'Ethnic cleansing' took place during the Bosnian war (1992-5). Lambrichs (2005) also subsequently wrote about the wars in the former Yugoslavia.

\section{Works cited}

Abraham, Nicolas and Maria Torok (2001) L'Écorce et le noyau (Paris: Flammarion). 
Bernstein, Michèle (1993) 'Nothomb, Lambrichs, saboté, avorté', Libération (21 October), 25.

Best, Victoria (2002) 'Louise L. Lambrichs: trauma, dream and narrative', in Women's Writing in Contemporary France: New Writers, New Literatures in the 1990s (Manchester: Manchester University Press), 29-41.

and Kathryn Robson (eds) (2005) Memory and Innovation in the PostHolocaust Generation in France, special issue, French Studies 59.1 (January).

Caruth, Cathy (1996) Unclaimed Experience: Trauma, Narrativity and History (Baltimore and London: The Johns Hopkins University Press).

Cusset, Catherine (2001) [1999] Le Problème avec Jane, rev. edn (Paris: Gallimard).

Darrieusscq, Marie (1996) Truismes (Paris: P.O.L.).

Davis, Colin (2005) 'État présent: hauntology, spectres and phantoms', French Studies 59.3 (July), 373-9.

Détrez, Christine, and Anne Simon (2006) À leur corps defendant: les femmes à l'épreuve du nouvel ordre moral (Paris: Seuil).

Eliacheff, Caroline, and Nathalie Heinich (2002) Mères-filles: une relation à trois (Paris: Albin Michel).

Ernaux, Annie (1974) Les Armoires vides (Paris: Gallimard). (2000) L'Événement (Paris: Gallimard).

Forrester, Viviane (1993) 'Hannah, jour et nuit', Le Monde (10 September).

Frey, Pascale (1993) 'La double vie d'Hannah égarée entre rêve et réalité' (interview with Louise L. Lambrichs), Tribune de Genève (11-12 September). (1994) 'Les 20 meilleurs livres de l'année', Lire (January).

Gazier, Michèle (1995) Nativités (Paris: Seuil). 
Gratton, Johnnie (2005) 'Postmemory, prememory, paramemory: the writing of Patrick Modiano', in Memory and Innovation in the Post-Holocaust Generation in France, ed. Victoria Best and Kathryn Robson, special issue, French Studies 59.1 (January), 39-45.

Greenberg, Wendy N. (1995) 'Review of Journal d'Hannah', The French Review 68.4 (March), 748-9.

Huston, Nancy (1996) Instruments des ténèbres (Arles: Actes Sud).

LaCapra, Dominick (1998) History and Memory after Auschwitz (Ithaca and London: Cornell University Press).

Lambrichs, Louise L. (1993) La Vérité médicale: Claude Bernard, Louis Pasteur, Sigmund Freud, méthodes et réalités de notre médecine (Paris: Éditions Robert Laffont).

(1995) Le Livre de Pierre: psychisme et cancer (Paris: Éditions de la Différence; 2nd edn Éditions du Seuil, 1998).

(1998) Hannah's Diary, trans. Siân Reynolds (London: Quartet Books).

(2002) [1993] Journal d'Hannah (Paris: Éditions de l'Olivier/Le Seuil; 1st edn Éditions de la Différence).

(2004) [1998] 'À notre image?', in À ton image (Paris: Éditions de l'Olivier/Le Seuil), 11-49.

(2005) Nous ne verrons jamais Vukovar (Paris: Éditions Philippe Rey).

Lasserre, Audrey (2002) 'Le roman français contemporain aux prises avec l'Histoire: Dora Bruder de Patrick Modiano et La Compagnie des spectres de Lydie Salvayre', Sites: The Journal of Twentieth-Century/Contemporary French Studies 6.2 (Autumn), 327-36. 
Miller, Nancy K. and Jason Tougaw (eds) Extremities: Trauma, Testimony and Community (Urbana and Chicago: University of Illinois Press).

Montremy, J.-M. de (1993) 'La maison de secret', La Croix-L'Événement (3-4 October).

Motte, Warren (2008) Fiction Now: The French Novel in the Twenty-First Century (Champaign and London: Dalkey Archive Press).

Nobécourt, Lorette (1998) La Conversation (Paris: Grasset).

Perrier, Jean-Claude (2004) 'Louise attaque', Livres Hebdo (17 December).

Remy, Jacqueline (1993) 'Une enfant de rêve', L'Express (7 October).

Rosnay, Tatiana de (2007) Elle s'appelait Sarah, trans. Agnès Michaux (Paris: Éditions Héloïse d'Ormesson).

Sardin, Pascale (2008) 'Towards an ethics of witness, or the story and history of "une minuscule détresse" in Annie Ernaux's L'Événement and Nancy Huston's Instruments des ténèbres', French Studies 62.3 (July), 301-12.

Silverman, Max (2008) 'Interconnected histories: Holocaust and Empire in the cultural imaginary', French Studies 62.4 (October), 417-28.

Todorov, Tzvetan (1998) Les Abus de la mémoire (Paris: Arléa).

Verdussen, Monique (1993) 'Le cri retenu du “Journal d'Hannah”', La Libre Belgique (20-21 November).

Whitehead, Anne (2004) Trauma Fiction (Edinburgh: Edinburgh University Press).

Wolf, Joan B. (2004) Harnessing the Holocaust: The Politics of Memory in France (Stanford CA: Stanford University Press). 